ELORE (ISSN 1456-3010), vol. 19 - 1/2012.

Julkaisija: Suomen Kansantietouden Tutkijain Seura ry.

[http://www.elore.fi/arkisto/1_12/lukin_kirja.pdf]

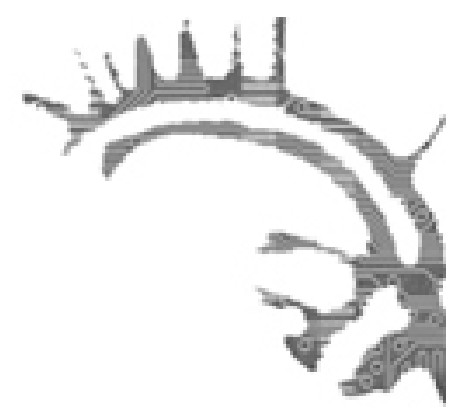

KIRJA-ARVIO

\title{
VENÄLÄINEN (UUS)PAKANUUS JA NEUVOSTOPERINTÖ
}

AITAMURTO, KAARINA 2011: Paganism, Traditionalism, Nationalism. Narratives of Russian Rodnoverie. Helsinki: Department of World Cultures. Omakustanne. 312 sivua.

Karina Lukin

Kaarina Aitamurron uskontotieteen väitöskirja Paganism, Traditionalism, Nationalism. Narratives of Russian Rodnoverie käsittelee sekä Venäjällä että Venäjän ulkopuolella vähän tutkittua, äärettömän laajaa ja monimuotoista uususkonnollista yhteisöä. Kirja on arvokas johdanto tämän rodnoverije-liikkeen historiallisiin ja kulttuurisiin taustoihin, opillisiin keskusteluihin ja myös käytäntöihin.

Tutkimuksen kolme ensimmäistä päälukua taustoittavat ilmiötä sekä sen tulkintaa ja kattavat yli puolet teoksen sivumäärästä. Aineistojen analyysille on omistettu niin ikään kolme erillistä lukua, jotka käsittelevät rodnoverijen julkaisujen pääasiallisia teemoja. Vaikka väitöskirja on monille opinnäytetyölle tyypillisesti etupainotteinen, etenkin Aitamurron huolella laatima rodnoverije-liikkeen taustoitus on ehdottomasti paikallaan. Sen avulla tulkinnan kohteena oleva uskonnollisuus asettuu venäjää taitamattomillekin lukijoille hienosti omaan kulttuuriseen, yhteiskunnalliseen ja historialliseen kontekstiinsa. Näin jo alusta asti tulee selväksi, että venäläisen uususkonnollisuuden vertaaminen länsimaiseen, vastaavasti nimitettävään ilmiöön on vähintäänkin hankalaa.

Rodnoverije asemoituu kenttään, jonka taustalla on niin äärinationalismia ja fasismia kuin romantiikkaakin, ja sen varhaiset jäsenet ja monet nykyisistä johtajista edustavat tekniikan alan älymystöä, fyysikkoja ja insinöörejä. Aitamurron oman arvion mukaan 
liikehdinnän ympärillä on nykyään vähintään 10000 ihmistä, joiden diskurssin ja toiminnan keskeisiä piirteitä ovat muun muassa slaavilaiseen tai venäläiseen yhteisöön keskittyminen, luonnonilmiöiden jumalallisuuden korostaminen ja toisistaan poikkeavat, usein ulkona toteutettavat rituaalit.

\section{KANSA, KANSAKUNTA}

Kirjan kolme analyysilukua keskittyvät niihin laajoihin teemoihin eli kertomuksiin, jotka ovat Aitamurron tutkimuksen tuloksia. Ensimmäinen kertomus keskittyy nationalistisiin teemoihin, toinen liikkeen pluralistisiin painotuksiin ja kolmas vieraantumiseen, jonka lääkkeenä rodnoverijen sanotaan toimivan. Tutkimuksen loppuluvussa Aitamurto toteaa, että luonto ja ekologiset näkökulmat ovat liikkeessä laajimmin hyväksyttyjä ja käytetyimpiä teemoja, jotka leikkaavat myös kaikkia analysoituja kokonaisuuksia. Tästä huolimatta itselleni päällimmäiseksi jäi mieleen etninen venäläisyys, joka kiinnittyy sekä laajempaan slaavilaisuuteen että varsin arkipäiväiseen etnisesti venäläisiä edustavien ihmisten kokemukseen siitä, mitä heidän kulttuurinsa tai perinteensä on. Olinkin hieman hämmentynyt siitä, että etnisen venäläisyyden teema ei noussut tutkimuksessa voimakkaammin esiin, vaan Aitamurto käsittelee näitä teemoja venäläisen nationalismin kontekstissa.

Ongelmanasettelu ei ilmeisesti nouse esiin Aitamurron analysoimissa teksteissä sinänsä. Rodnoverije-tekstien nationalistisessa kertomuksessa luodaan mielikuva kansakunnassa, joka menetti muinaisen kukoistuksensa ja itsetuntonsa hylätessään perintönsä ja ihannoidessaan ja jäljitellessään vieraita malleja. Vieraudella viitataan muun muassa länsimaisiin ideologioihin kristinuskosta marxismiin. Tämä kertomus on yleisempi malli, joka asettuu kyllä venäläisen nationalisminkin raameihin, sillä ne ovat myös etnisesti venäläiset. Silti rodnoverije-tekstien käyttämät ilmaisut, kuten esimerkiksi rod (suom. suku, syntyperä, heimo) viittaavat sellaisenaan nimenomaan etniseen venäläisyyteen, eivät koko monikulttuuriseen kansakuntaan. Tällaisena liike poikkeaa Venäjän Ortodoksisesta Kirkosta, jonka kieli vetoaa nimenomaan venä(jä)läisiin kansakuntana ja jonka suosio ylittää Venäjän Federaation sisällä vaivatta myös etniset rajat. Sen sijaan rodnoverije lienee etnisesti venäläisten harjoittamaa uskonnollisuutta.

Kyseinen nationalistinen painotus tekee rodnoverijestä omalaatuisen länsimaalaisessa uusien uskontojen kentässä, mutta erottaa sen myös muista Venäjän federaation alueen paikallisista uskonnoista. Näitä onkin totuttu tarkastelemaan etnisenä liikehdintänä, joilla on oma paikallispolitiikkansa, mutta ei kansallisen itsemääräämisoikeuden tai globaalien missioiden teemoja. Sen sijaan Aitamurron hahmottamat kaksi muuta kertomusta teemoineen asettuvat samoihin raameihin kuin paikalliset etniset uskonnot, joissa samalla tavoin kuin rodnoverijessä korostetaan luontosuhdetta, luonnon jumalallisuutta, uskonnollisuutta osana jonkinlaista vaihtoehtoisuutta sekä omille juurille paluun tärkeyttä. Tällaisessa kontekstissa rodnoverije ei asetu Neuvostoliiton jälkeisen Venäjän uskonnontutkimuksessa liialtikin käytettyyn ja helppoon argumenttiin arvotyhjiöstä. Myös Aitamurto vierastaa tyhjiö-selitystä ja näkee loppuluvussa liikkeen mieluummin uskonnollisena perinteenä kuin liikkeenä. Tällä hän viitannee juuri liikkeen etnisyy- 
teen ja siihen, että taustalla on eläviä tai elvytettyjä venäläisiä perinteitä, vaikka ei sitä muutoin tuokaan esiin tutkimuksessa.

\section{Pinnalla}

Kokonaisuudessaan tutkimuksessa tuodaan esiin laaja kirjo rodnoverije-liikkeen alla käytyä keskustelua ja kirjallisuutta. Kirjan parhaana antina voikin pitää sitä, että se esittelee heterogeenistä liikettä monipuolisesti ja ikäviäkään teemoja kaihtamatta. Esimerkiksi liikkeen sisällä toistuvat, rasistiset juutalaisten salaliittoja koskevat teoriat tulevat ansiokkaasti käsitellyiksi.

Aitamurto on tekstien keräämisen lisäksi tehnyt myös kenttätöitä eri rodnoverijeliikkeiden parissa. Kenttätöiden tarkoituksena on ollut valottaa tutkijalle, millaista toimintaa tekstien taustalla on ja monipuolistaa kuvaa. Tutkimuksessa kenttätyökuvaukset toimivat niin ikään mainioina dogmaattisten keskustelujen ja arkipäivän valintojen avaajina. Esimerkiksi käsitellessään liikkeen keskusteluja luonnosta, kotimaasta ja näiden pyhittämisestä Aitamurto tuo esiin, että myös rodnoverijen kannattajat vierailevat eurooppalaisissa turistikohteissa ja ottavat niissä valokuvia, jotka ovat kuin mitkä tahansa turistivalokuvat kohteiden edessä poseeraavista ihmisistä. Valokuvaalbumit sisältävät kuitenkin myös huomattavan määrän luonnonilmiöitä ja venäläistä maisemaa, millä ilmaistaan luonnon ihailun lisäksi vaihtoehtoisuutta.

Tutkimuksen näkökulma on uskontososiologinen ja tällaisena se kartoittaa rodnoverijen taustalla olevia ajatuskokonaisuuksia, niiden välisiä suhteita ja niiden suhteita venäläiseen ja neuvostoajatteluun sekä länsimaiseen jälkimoderniin uskonnollisuuteen. Teemat tulevat selkeästi esiin, mutta Aitamurto käy niitä läpi vauhdilla. Yksittäisistä teemoista ja niiden alateemoistakin olisi voinut saada vielä paljon enemmän irti. Joko kyse on uskontososiologisen näkökulman erilaisuudesta suhteessa edustamaani etnografispainotteiseen näkökulmaan tai sitten tutkimus on tehty kiireellä. Jälkimmäistä epäilen etenkin viimeistä vieraantumiseen liittyvää analyysilukua lukiessani, sillä se on ohuempi kuin ensimmäinen, nationalistista kertomusta käsittelevä analyysiluku. Etnografi olisi kenties keskittynyt yhteen teemaan syvällisesti ja folkloristi olisi tuonut esiin enemmän esimerkkejä rodnoverije-kirjoittelusta. Nyt tutkimuksen konteksti on hyvin laaja ja sen analyysi pysyy tekstien pintatasolla.

\section{VENÄLÄINEN ILMIÖ}

Aitamurto on asettanut tutkimukselle kaksi tehtävää. Ensimmäisen tehtävä on ollut vastata siihen, miten ja miksi rodnoverije vetoaa moderniin, venäläiseen yhteiskuntaan ja sen jäseniin tai miten rodnoverijen jäsenet itse selittävät uskontonsa suosion nykyVenäjällä. Itse asiassa tutkija ei mielestäni vastaa tähän kysymykseen, mikä johtuu siitä, ettei tekstipainotteinen aineisto tarjoa vastauksia siihen. Systemaattisempi kenttätyö olisi voinut mahdollistaa vastaamisen, mutta Aitamurto ei ole käyttänyt kenttätyö- 
aineistoa tähän tarkoitukseen. Kenttätyöaineisto sen sijaan on selkeästi tuonut sekä tutkijan näkökulmaan syvyyttä että tutkimukseen toden tuntua, sillä muutoin teoksessa liikutaan sangen dogmaattisten, liikkeen aktiivisten kirjoittajien tekstien tasolla.

Korkeamman abstraktiotason kysymykset kiinnostavatkin selkeästi Aitamurtoa, kuten myös laajempi keskustelu jälkimodernista uskonnollisuudesta. Hän on asettanut tutkimuksen toiseksi tehtäväksi arvioida näiden keskustelujen käytettävyyttä nyky-Venäjällä. Teoksessa esitellään jälkimodernin uskonnon teorioita laajasti sekä johdannossa että itse analyysissä tarpeen tullen. Vertailut teorioiden ja rodnoverijen käytäntöjen ja tekstien välillä ovat onnistuneita ja ne osoittavat, miten monimuotoinen liike rodnoverije on ja miten siitä sen vuoksi voi löytää sekä yhteneväisyyksiä että eriäväisyyksiä suhteessa länsimaisiin uususkollisiin ilmiöihin.

Käsittääkseni Aitamurto ei ole taipuvainen asettamaan rodnoverijetä länsimaisen jälkimodernin uskonnollisuuden kontekstiin vaan sellaisiin kehyksiin, joita luonnehtii edelleenkin löyhästi Neuvostoliiton jälkeisyys. Tällä tavalla rodnoverijetä on helpompi verrata latvialaisiin tai puolalaisiin uskonnollisiin liikkeisiin - toisin kuin esimerkiksi brittiläisiin. Venäjäntutkijat ovat tätä nykyä väsyneet Neuvostoliiton jälkeisyyteen (postSoviet), sillä sen ei katsota enää, yli 20 vuotta imperiumin hajoamisen jälkeen, olevan relevantti näkökulma venäläiseen tai itäeurooppalaisiin yhteiskuntiin. Aitamurto onkin onnistunut näyttämään, että nyky-Venäjällä uskonnollisuus asettuu omalaatuiseen kenttään, jonka monet käytännöt ja diskurssit tai kertomukset on palautettavissa neuvostoperintöön, mutta joita ei enää hallitse yhteiskunnallinen murros.

Filosofian tohtori Karina Lukin on helsinkiläinen folkloristi, joka on tutkinut Pohjois-Venäjällä asuvien nenetsien uskonnollisuutta. 